\title{
Taxonomy and palaeobiogeographical significance of four new species of Semicytherura (Ostracoda, Crustacea) from the Early Pleistocene Omma Formation of the Japan Sea coast
}

\author{
HIROKAZU OZAWA ${ }^{1} \&$ TAKAHIRO KAMIYA ${ }^{2}$ \\ ${ }^{1}$ Department of Geology, National Museum of Nature and Science, Tokyo, 3-23-1 Hyakunin-cho, Shinjuku-ku, Tokyo 169-0073, Japan \\ (e-mail: ozawahi@kahaku.go.jp) \\ ${ }^{2}$ School of Natural System, College of Science and Engineering, Kanazawa University, Kakuma-machi, Kanazawa 920-1192, Japan
}

\begin{abstract}
The genus Semicytherura (Ostracoda, Crustacea) is distributed widely in shallow-sea areas of the Northern Hemisphere and occurs commonly in Pliocene and Pleistocene strata along the Japan Sea coasts. Four new species - Semicytherura robustundata sp. nov., Semicytherura subslipperi sp. nov., Semicytherura leptosubundata sp. nov. and Semicytherura tanimurai sp. nov. - are described from the Early Pleistocene Omma Formation, central Japan. These species are palaeobiogeographically significant in the history of species diversity changes in Japan Sea benthic fauna during the Late Cenozoic. The geological and geographical occurrences suggest that these four species originated within the Japan Sea from the Late Pliocene, including one species that diversified by heterochronic evolution, and were endemic to the Japan Sea. They became extinct within this sea during the Early Pleistocene. $J$. Micropalaentol. 27(2): 135-146, November 2008.
\end{abstract}

KEYWORDS: ostracods, Semicytherura, Japan Sea, Plio-Pleistocene, extinction

\section{INTRODUCTION}

The genus Semicytherura (Family Cytheruridae) established by Wagner (1957) is distributed widely in the shallow marine environment of the Northern Hemisphere. It is estimated to contain over 200 species world-wide and occurs commonly in and around the modern Japanese Islands (Hanai, 1957; Okubo, 1980; Yamada et al., 2005), where approximately 20 species have been described (Ikeya et al., 2003). Thus, this genus is important among the podocopid ostracod faunas of Japan.

Semicytherura species are found commonly in shallow marine strata of the Late Cenozoic along the Japan Sea coast (e.g. Ishizaki \& Matoba, 1985; Cronin \& Ikeya, 1987). Significant fossil occurrences of some Semicytherura species have been found along the Japan Sea coast, providing valuable diversity evidence in this area since the Miocene (Irizuki, 1994; Ozawa, 2007). Recent studies have summarized changes in species diversity in three ostracod families - Cytheruridae, Hemicytheridae and Eucytheridae - of the Japan Sea coast, as related to Pleistocene oceanographical environmental changes induced by glacio-eustatic cycles (Ozawa \& Kamiya, 2005), and have shown the palaeontological significance of Semicytherura species from the Japan Sea.

However, in and around Japan, undescribed Semicytherura species have been placed in more than 40 taxa (Yamada et al., 2005). The Early Pleistocene Omma Formation in central Japan contains many fossil ostracods, including Semicytherura (Ozawa, 1996). Some undescribed Semicytherura from the Omma Formation are found only in Pliocene-Pleistocene strata along the Japan Sea coast, where they were once endemic but are now extinct (Ozawa \& Kamiya, 2005). Previous studies did not cover detailed examinations of the carapace morphology of these Semicytherura taxa or categorize them into new species because of their small carapace size and very high diversity, including many undescribed species in this region.

Four new species of the genus Semicytherura are described here from the Japanese Pleistocene (Omma Formation), including detailed morphological observations. Furthermore, this article briefly discusses their palaeobiogeographical significance, history of diversity changes with related species during the Late Cenozoic in and around the Japan Sea, and related environmental factors.

\section{MATERIAL AND METHODS}

Fossil specimens of four species of the genus Semicytherura were re-examined in 36 samples from the Sakuramachi area (samples C201-C509, studied by Ozawa \& Kamiya, 2001) from the Early Pleistocene Omma Formation (1.7-1.4 Ma; Takata, 2000), central Japan (Fig. 1). To clarify the geological occurrences of

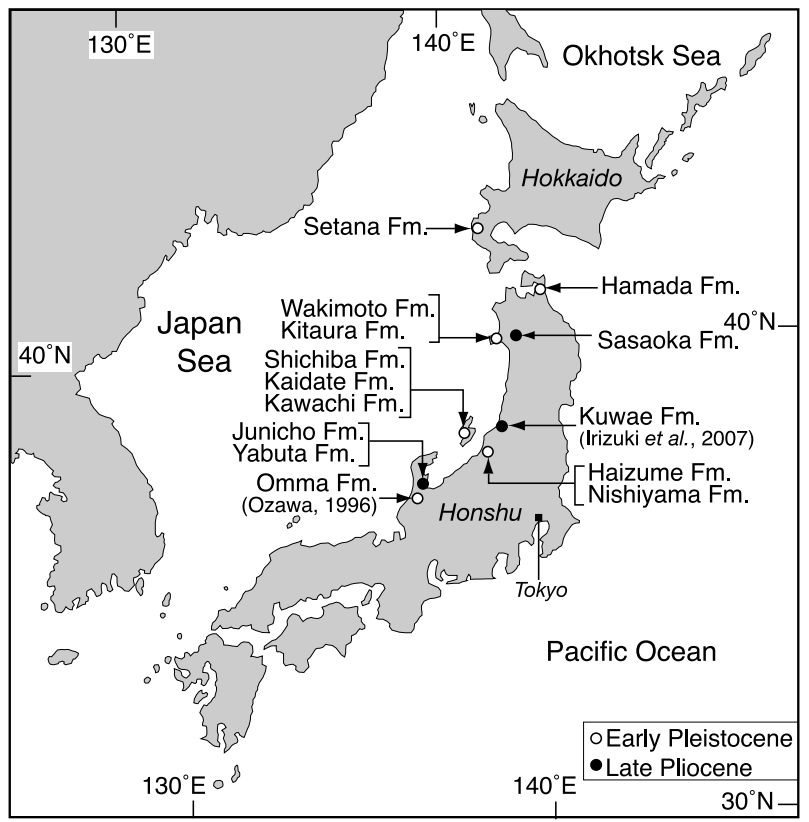

Fig. 1. Geographical and geological occurrences of the four Semicytherura species described based on original data, except for occurrences from the Omma Formation (Ozawa, 1996) and Kuwae Formation (Irizuki et al., 2007). Fm, Formation. 
these four species, fossil ostracods from a series of 48 samples of Pliocene and Pleistocene strata from the Japan Sea coast (Fig. 1), used by Ozawa \& Kamiya (2005), were also examined. Ostracod data were added from two samples from the Early Pleistocene Nishiyama Formation (1.3 Ma; Sato et al., 1987), central Japan (Fig. 1). For comparison with the carapace morphology of one of these four species, Semicytherura subundata (Hanai, 1957) was also examined from an Early Pleistocene sample from the Kaidate Formation (1.0 Ma; Kato et al., 1995), central Japan (Fig. 1), studied by Ozawa \& Kamiya (2005). Carapaces were observed using a scanning electron microscope (JEOL-JSM-5310) and a binocular microscope.

\section{SYSTEMATIC DESCRIPTIONS OF NEW SPECIES}

All type specimens are deposited in the collections of the National Museum of Nature and Science, Tokyo, Japan, identified by numbers with the prefix MPC (Micropaleontology Collection, National Museum of Nature and Science, Tokyo). The type locality and the sample number for the four new species equates to the same location within the Sakuramachi area and the same sample numbers in Ozawa \& Kamiya (2001), respectively.

Superfamily Cytheracea Baird, 1850

Family Cytheruridae G. W. Müller, 1894

Subfamily Cytherurinae G. W. Müller, 1894

Genus Semicytherura Wagner, 1957

Semicytherura robustundata $\mathrm{sp}$. nov. (Pl. 1, figs 1-8)

1996 Semicytherura cf. undata (Sars, 1866); Ozawa: 115, pl. 9, fig. 3.

2005 Semicytherura cf. undata (Sars, 1866); Ozawa \& Kamiya: 179, fig. 7.10.

2007 Semicytherura cf. undata (Sars, 1866); Ozawa: 25, fig. 4.14.

Derivation of name. From its resemblance to Semicytherura undata (Sars, 1866) and in having a more robust surface ornamentation.

Diagnosis. Carapace is small, sub-quadrangular and heavily calcified. The surface is covered with large fossae, numerous fine pits and several large reticulations at the mid-dorsal to posterodorsal parts. Strong ridges are present; the anterior ridge starts in the antero-ventral part, runs posteriorly, connecting with one short-vertical ridge starting at the median part; two thick, prominent ridges cross approxiamtely at right angles in the antero-dorsal part, in a T-shape.

Holotype. Female, right valve, MPC-02986, from sample C505 (Pl. 1, figs 1, 7, 8).

Paratypes. Male, complete carapace, MPC-02987 from sample C505 (P1. 1, fig. 3). Female, left valve, MPC-02988, from sample C505 (P1. 1, fig. 2). Male, complete carapace, MPC-02989, from sample C505 (P1. 1, fig. 5). Female, right valve, MPC-02990, from sample C505 (Pl. 1, fig. 4). Male, left valve, MPC-02991, from sample C304 (Pl. 1, fig. 6).
Type locality and age. Sakuramachi area of Ozawa \& Kamiya (2001), the Early Pleistocene Omma Formation (Fig. 1), Oyabe City, Toyama Prefecture, central Japan (Lat. $36^{\circ} 41.1^{\prime}$ N, Long. $\left.136^{\circ} 52.1^{\prime} \mathrm{E}\right)$

Description. Thick and heavily calcified carapace. Small valve, sub-quadrangular in lateral view. Maximum height near the valve at mid-length. Dorsal margin is slightly arched. Ventral margin is nearly straight. Antero-dorsal margin is smooth, obliquely rounded; antero-ventral margin, with several small spines, is curved near the ventral margin; posterior margin with slightly curved section above the posterior caudal process. Short and blunt caudal process, one-third of the valve height.

The carapace surface is ornamented by strong ridges; two prominent ridges crossed at nearly right angles at the anterodorsal area in a T-shape; one along the ventral margin, connecting with one short vertical ridge starting at the median area; one small U-shaped ridge in the antero-median area, connected with the $\mathrm{T}$-shaped ridge and with one short-straight ridge in a vertical line at the mid-ventral area. Marginal ridges surrounded in the valve.

Large reticulation with surrounding ridges, at the anterodorsal to postero-dorsal areas, subparallel to the dorsal margin; one elongate fossa at the mid-posterior area, surrounded by ridges. Numerous fine pits distributed over the carapace. Reticulation is well developed, except on the major ridges and along the dorsal, ventral and posterior marginal areas; several triangle fossae occur at the postero-median area. Eye tubercle is indistinct. Normal pores are observed on the valve surface.

Hingement: in the right valve, the anterior element consists of one small socket and two adjacent rounded teeth, a large and projecting front tooth, small rear tooth; smooth median element; posterior element consists of one small, rounded and projecting tooth, with one adjacent shallow and large socket. Hinge line is slightly curved.

Four adductor muscle scars occur in a straight, ventromedian position, vertical line; the uppermost and lowermost scars are semi-circular, whereas the middle two scars are slightly elongate or bone-shaped; two oval frontal scars lie in front of the upper two adductor scars. The marginal infoldment and prismatic layer are very broad in the male, especially in the posterior area. Vestibule was not observed.

Sexual dimorphism is distinct. The carapace of the male is more slender and longer than the female in lateral view.

Dimensions (mm). Holotype, length $(\mathrm{L})=0.63$, height $(\mathrm{H})=0.37$ (female, right valve, MPC-02986). Paratypes, $\mathrm{L}=0.54, \mathrm{H}=0.30$ (male, carapace, MPC-02987); $\mathrm{L}=0.58, \mathrm{H}=0.36$ (female, left valve, MPC-02988); $\mathrm{L}=0.50, \mathrm{H}=0.27$ (male, carapace, MPC02989); $\mathrm{L}=0.60, \mathrm{H}=0.36$ (female, right valve, MPC-02990); $\mathrm{L}=0.54, \mathrm{H}=0.30$ (male, left valve, MPC-02991).

Occurrence. Pliocene to Pleistocene, Japan; Late Pliocene Sasaoka Formation and Early Pleistocene Omma, Hamada and Kitaura formations from the Japan Sea coast (Fig. 1).

Remarks. The present species resembles Semicytherura undata (Sars, 1866), figured by Athersuch et al. (1989, p. 220, fig. 91A-B; p. 359, pl. 7, fig. 10) from the Recent of the British Isles, 


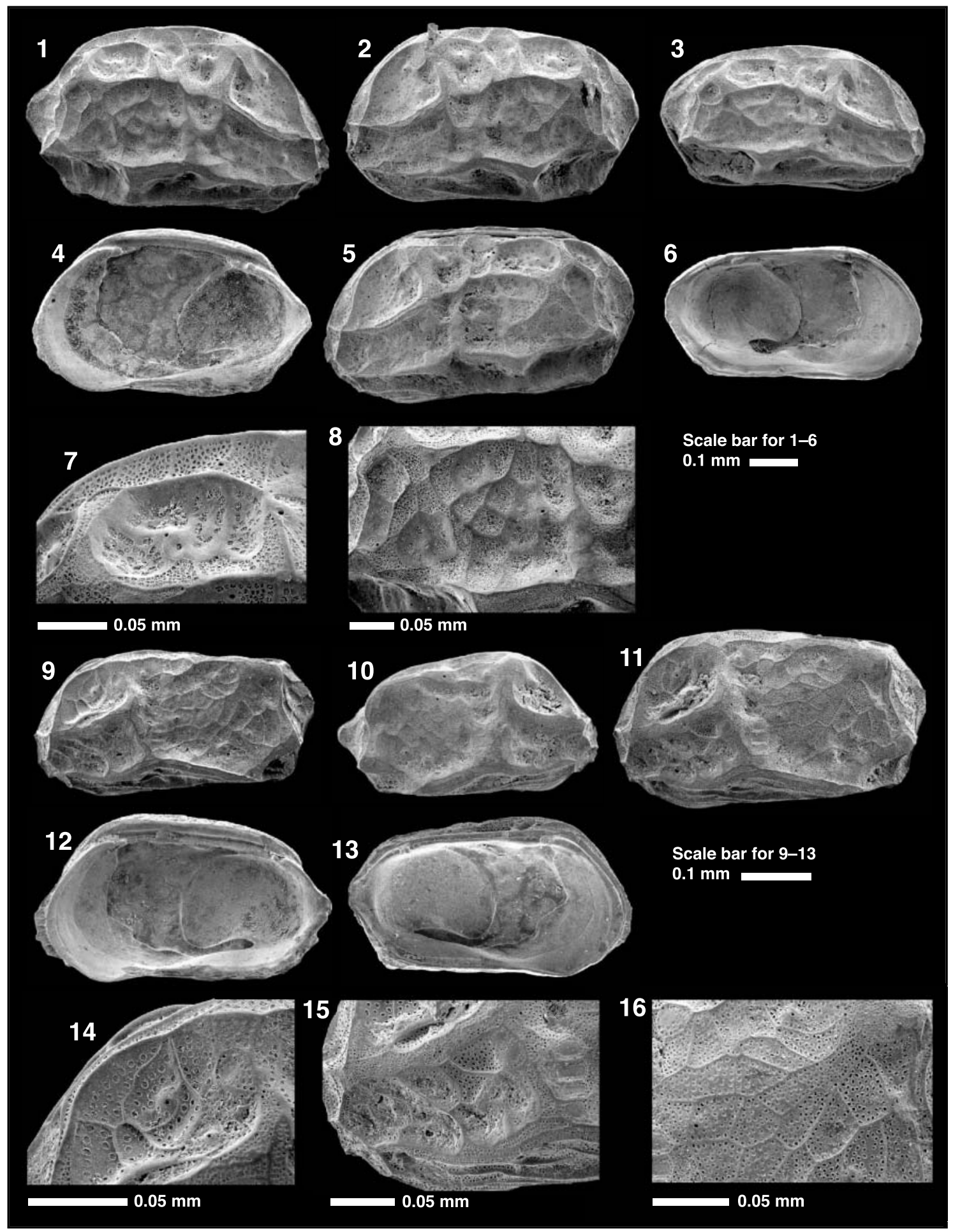

Explanation of Plate 1.

figs 1-8. Semicytherura robustundata sp. nov.: 1, female, right valve (holotype, MPC-02986); 2, female, left valve (paratype, MPC-02988); 3, male, carapace, right side (paratype, MPC-02987); 4, female, right valve from inside (paratype, MPC-02990); 5, male, carapace, left side (paratype, MPC-02989); 6, male, left valve from inside (paratype, MPC-02991); 7, close-up view of fossae and pores in postero-dorsal area of female on right valve (holotype, MPC-02986); 8, close-up view of reticulations, ridges and pores in postero-median area of female on right valve (holotype, MPC-02986). figs 9-16. Semicytherura subslipperi sp. nov.: 9, male, left valve (holotype, MPC-02992); 10, male, right valve (paratype, MPC-02993); 11, female, left valve (paratype, MPC-02994); 12, female, right valve from inside (paratype, MPC-02996); 13, female, left valve from inside (paratype, MPC-02995); 14, close-up view of reticulations and pores in antero-dorsal area of male on left valve (holotype, MPC-02992); 15, close-up view of ridges and reticulations in antero-ventral area of female on left valve (paratype, MPC-02994); 16, close-up view of reticulations in postero-median area of female on left valve (paratype, MPC-02994). Specimens 1-5, 7-9, 14 from sample C505; 6, 10, 11, 13, 15, 16 from C304; and 12 from C403. 
in general external carapace ornamentation and carapace size. However, it differs from $S$. undata in valve outline and the nature of the valve surface. The overall outline of this species is sub-quadrangular in lateral view. This species displays large reticulations with surrounding ridges at the antero-dorsal to postero-dorsal parts, subparallel to the dorsal margin. Several triangular fossae at the postero-median area are developed in this species.

This species is also similar to Semicytherura subundata (Hanai, 1957, p. 35, figs 3a, b; p. 39; pl. 2, figs 3a, b), from the Pleistocene Sawane Formation, central Japan, in general external carapace morphology. However, it differs from $S$. subundata in having a smaller valve, in valve outline and the nature of the valve surface. The overall outline of this species is subquadrangular in lateral view. The present species has several large fossae with crater-shaped depressions at the antero-dorsal to postero-dorsal parts, with one elongate fossa at the posteromedian area. Large and triangular fossae develop in the median to postero-median areas of this species. S. subundata has one oblique ridge running from the postero-dorsal corner to the mid-ventral margin, but this species has no similar ridges.

It also resembles Semicytherura balrogi (Brouwers, 1994, pl. 5, figs 15-18; pl. 6, figs 1, 2; pl. 7, figs 1-3, 6), from Holocene sediments from the Gulf of Alaska, in general external morphology. However, it differs from $S$. balrogi in its much larger valve size, the valve outline of the posterior margin, the degree of development of the prominent ridges in the postero-dorsal and postero-ventral areas, and strong ridges and deep reticulations or fossae on the entire carapace.

The present species is similar to Semicytherura sp. 2 (Irizuki, 1994, pl. 3, fig. 7) and Semicytherura sp. 4 (Irizuki, 1994, pl. 3, figs 12-15), from the Late Miocene Fujikotogawa Formation, north Japan, in general external morphology. However, the present species differs in having a much larger valve and a different ridge pattern in its posterior half, and in having numerous fine surficial pits.

Semicytherura subslipperi sp. nov. (P1. 1, figs 9-16)

1996 Semicytherura sp. 4; Ozawa: 115, pl. 9, fig. 4. 2002 Semicytherura sp. 1; Yamada et al.: 122, pl. 1, fig. 15. 2005 Semicytherura sp. B; Ozawa \& Kamiya: 179, fig. 7.12. 2007 Semicytherura sp. B; Irizuki et al.: 430, fig. 7.8. 2007 Semicytherura sp. A; Ozawa: 25, fig. 4.15.

Derivation of name. After its resemblance to Semicytherura slipperi Yamada et al., 2005.

Diagnosis. The carapace is small, sub-rectangular and heavily calcified. The surface is ornamented by faint reticulations and three prominent ridges; two thick ridges cross at right angles in the antero-median areas forming a T-shape, and one major ridge lies along the ventral margin, connecting with a middle ridge starting in the antero-dorsal position. Short, blunt caudal process.

Holotype. Male, left valve, MPC-02992, from sample C505 (P1. 1, figs 9, 14).
Paratypes. Male, right valve, MPC-02993, from C304 (P1. 1, fig. 10). Female, left valve, MPC-02994, from sample C304 (Pl. 1, figs 11, 15, 16). Female, left valve, MPC-02995, from sample C304 (Pl. 1, fig. 13). Female, right valve, MPC-02996, from C403 (Pl. 1, fig. 12).

Type locality and age. Sakuramachi area of Ozawa \& Kamiya (2001), the Early Pleistocene Omma Formation (Fig. 1), Oyabe City, Toyama Prefecture, central Japan (Lat. $36^{\circ} 41.1^{\prime}$ N, Long. $\left.136^{\circ} 52.1^{\prime} \mathrm{E}\right)$.

Description. Thick and heavily calcified carapace. Small valve, sub-rectangular in lateral view. Maximum height at the anterior cardinal angle. The dorsal margin is nearly straight in the left valve, slightly arched in the right valve. The ventral margin is slightly convex. The antero-dorsal margin is smooth, obliquely rounded; the antero-ventral margin, with several small spines, is curved near the ventral margin. Short and blunt caudal process at mid-height in the right valve. The right valve has a posterior margin with a slightly concave section above the posterior caudal process and nearly straight section below the caudal process. In the left valve the posterior margin is curved.

The valve surface is ornamented by three prominent ridges; two thick ridges cross at right angles in the antero-median areas in a T-shape, and one major ridge runs along the ventral margin, connecting with one middle ridge starting at the antero-dorsal part, in a T-shape. Marginal ridges surrounded in the carapace. Shallow dorso-median sulcus is developed. Numerous fine pits are distributed over the carapace; weak reticulation is developed, except on the major ridges and along the dorsal and ventral marginal areas. The eye tubercle is indistinct. Normal pores are found on the valve surface.

Hingement: in the right valve, the anterior element consists of one small tooth and two adjacent small sockets; the median element with numerous fine teeth, many fused teeth in the median and posterior parts; the posterior element consists of one small and rounded tooth, with two adjacent small sockets. Hinge line is nearly straight, descending posteriorly.

Four adductor muscle scars occur in a straight ventro-median position in a vertical line; the uppermost and lowermost scars are semi-circular, whereas the middle two scars are slightly elongate or bone-shaped; two oval frontal scars are in front of the upper two adductor scars. The marginal infoldment and prismatic layer are very broad, especially in the posterior area. The vestibule was not observed.

Sexual dimorphism is distinct. The male carapace is more slender and longer than the female in lateral view.

Dimensions (mm). Holotype, $\mathrm{L}=0.42, \mathrm{H}=0.22$ (male, left valve, MPC-02992). Paratypes, $\mathrm{L}=0.37, \mathrm{H}=0.21$ (male, right valve, MPC-02993); $\mathrm{L}=0.44, \mathrm{H}=0.27$ (female, left valve, MPC-02994); $\mathrm{L}=0.40, \mathrm{H}=0.22$ (female, left valve, MPC-02995); $\mathrm{L}=0.44$, $\mathrm{H}=0.26$ (female, right valve, MPC-02996).

Occurrence. Pliocene to Pleistocene, Japan; Late Pliocene Yabuta, Kuwae, Sasaoka and Junicho formations, and Early 


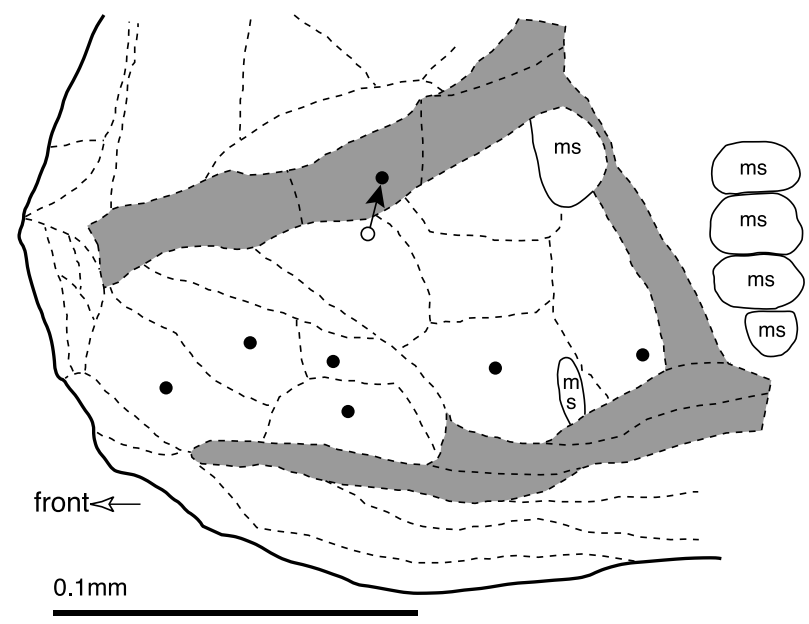

Fig. 2. Positions of seven pores on the antero-ventral part of the left valve of Semicytherura subslipperi sp. nov. Black spots show pores of $S$. subslipperi sp. nov.; the one white spot represents the difference in position of one pore between $S$. subslipperi sp. nov. and $S$. slipperi Yamada et al., 2005. Shaded areas correlate ridges at the anterior part. ms, muscle scar mold.

Pleistocene Omma, Nishiyama and Haizume formations from the Japan Sea coast (Fig. 1).

Remarks. This species is similar to Semicytherura slipperi, defined by Yamada et al. (2005, p. 247, fig. 2A; p. 250, fig. 4A-Y; p. 252, fig. 5A-L) from the Recent of Akkeshi Bay, northern Japan, in external carapace ornamentation and carapace size. However, it differs from $S$. slipperi in its valve outline, the nature of the valve surface and the position of one normal pore in the mid-anterior area (Fig. 2). In lateral view this species displays straighter dorso-median to postero-dorsal margins in outline and a more rounded outline in its antero-dorsal margin than $S$. slipperi. A slightly weak T-shaped ridge developed in the antero-median area, a straight ridge in the postero-ventral marginal area, relatively faint reticulation on the overall carapace, and a shallow dorso-median sulcus are found on the carapace of this species.

It is also similar to Semicytherura pseudoundata, defined by Irizuki et al. (2004, p. 143, pl. 9, figs 5-10) from the Early Miocene Toyama Formation, central Japan. However, S. pseudoundata has a broadly sigmoidal ventral ridge, a ridge running from the postero-dorsal corner to the median-ventral margin, a large and deep fossa in the postero-ventral area with no reticulations, and fine pits on the valve surface.

The present species is similar to Semicytherura henryhowei Hanai \& Ikeya, 1977 in Hanai et al. (1977), figured by Yamada et al. (2005, p. 247, fig. 2A; p. 249, fig. 3A-I) from the Recent Pacific coast of Miura Peninsula, central Japan, in general carapace morphology. However, it can be distinguished by clear reticulations, the position of the anterior $\mathrm{T}$-shaped ridge, and the number and position of normal pores in the antero-ventral area.

The present species also resembles Semicytherura sp. 3 of Irizuki (1994, pl. 3, figs 8-11), from the Late Miocene Fujikotogawa Formation, north Japan, in general external morphology. However, the present species differs in having a slightly smaller valve and weak ridge in its anterior half, with numerous fine reticulations and pits on the valve surface.

Specimens of Semicytherura sp. 4 of Ozawa (1996, p. 115, pl. 9, fig. 4) and Semicytherura sp. B of Ozawa \& Kamiya (2005, p. 179, fig. 7.12), reported from the same locality as the type specimens of $S$. subslipperi sp. nov., were judged to be abraded and not well-preserved specimens of $S$. subslipperi found in this study.

\section{Semicytherura leptosubundata sp. nov.}

(Pl. 2, figs 1-9)

1996 Semicytherura sp. 5; Ozawa: 115, pl. 9, fig. 5. 2005 Semicytherura sp. A; Ozawa \& Kamiya: 179, fig. 7.11. 2007 Semicytherura sp. B; Ozawa: 25, fig. 4.16.

Derivation of name. After its resemblance to Semicytherura subundata (Hanai, 1957) and having a smooth texture.

Diagnosis. The carapace is small sized and sub-trapezoidal. A thin valve occurs in the upper half and is heavily calcified in the lower half. The surface is covered with very faint reticulations and numerous fine pits. There is one marginal ridge from the antero-ventral to postero-ventral areas, one prominent ala in the ventro-marginal ridge, and a distinct caudal mid-valve process.

Holotype. Male, right valve, MPC-02997, from sample C304 (P1. 2, figs 1, 7).

Paratypes. Female, left valve, MPC-02998, from sample C304 (P1. 2, fig. 3). Female, right valve, MPC-02999, from sample C506 (P1. 2, figs 4, 8). Female, right valve, MPC-03000, from sample C505 (Pl. 2, fig. 6). Male, left valve, MPC-03001, from sample C304 (Pl. 2, fig. 5). Female, left valve, MPC-03002, from sample C403 (Pl. 2, figs 2, 9).

Type locality and age. Sakuramachi area of Ozawa \& Kamiya (2001), from the Early Pleistocene Omma Formation (Fig. 1) of Oyabe City, Toyama Prefecture, central Japan (Lat. $36^{\circ} 41.1^{\prime} \mathrm{N}$, Long. $\left.136^{\circ} 52.1^{\prime} \mathrm{E}\right)$.

Description. Thin carapace, especially in the upper half of the median to dorsal areas. Small valve, sub-trapezoidal in lateral view. Maximum height at one-quarter of the valve length. The dorsal margin is arched; the ventral margin is slightly concave. The antero-dorsal margin is obliquely rounded; the anteroventral margin, with several small spines, is curved near the ventral margin. There is a distinct caudal process, nearly midheight in the valve. The posterior margin has a slightly concave section above the posterior caudal process, and a nearly straight section below the caudal process. Sub-rhomboidal shape in dorsal and ventral view.

The valve surface is ornamented by one distinct ridge; a prominent ridge along the ventral margin, starting in the antero-ventral area, running posteriorly and terminating in the postero-dorsal area. One short faint crest starting from the antero-median margin, running posteriorly and terminating in the antero-central area. One prominent ala in the middle of one 

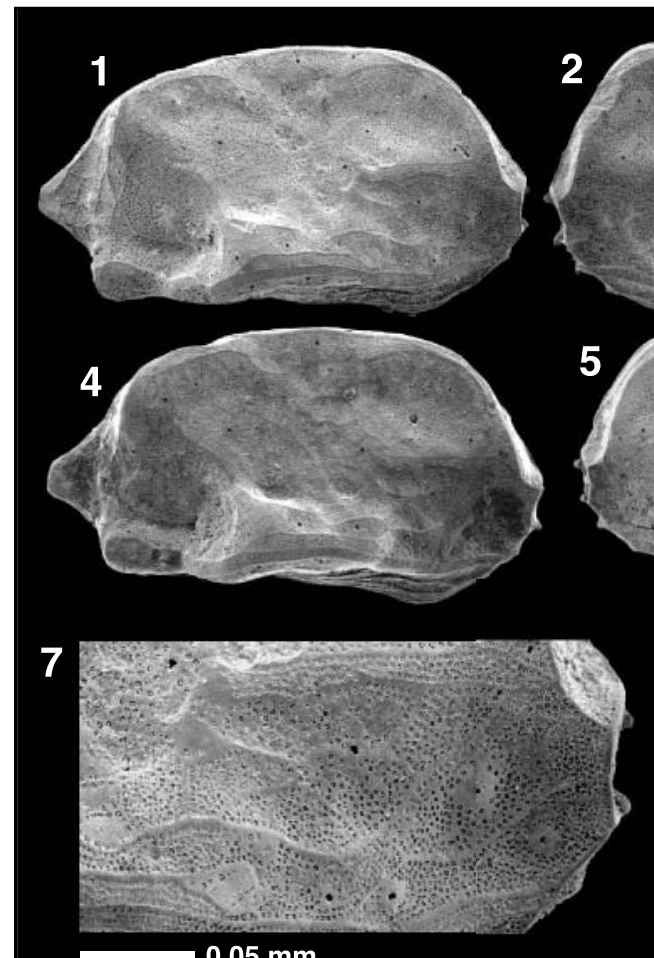
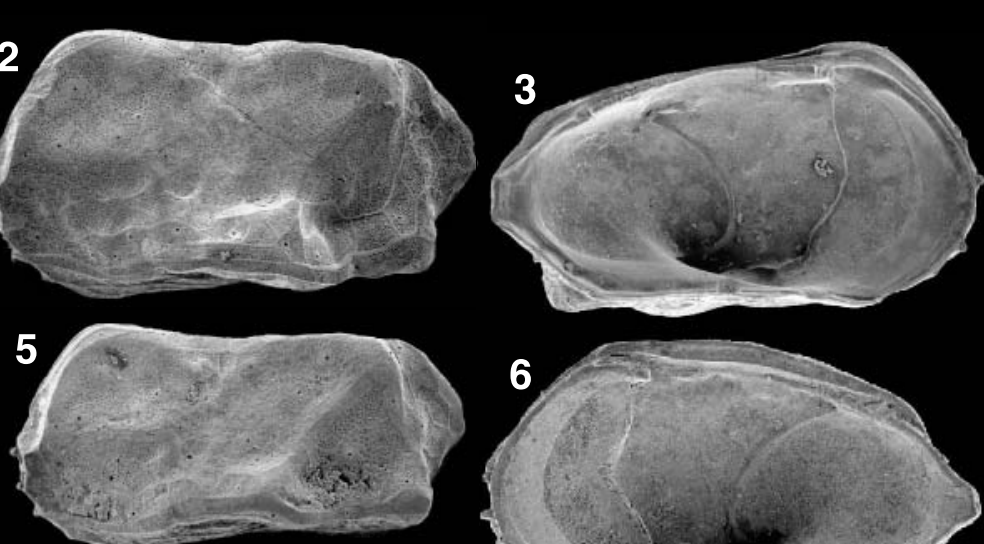

Scale bar for 1-6 $0.1 \mathrm{~mm}$

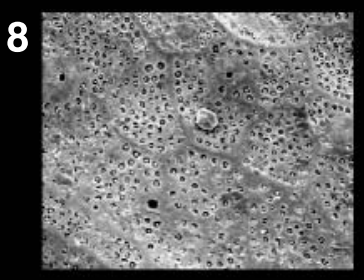

$0.05 \mathrm{~mm}$

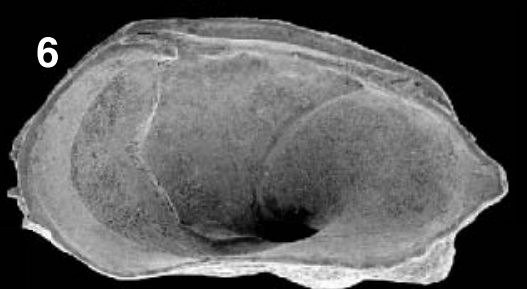

9
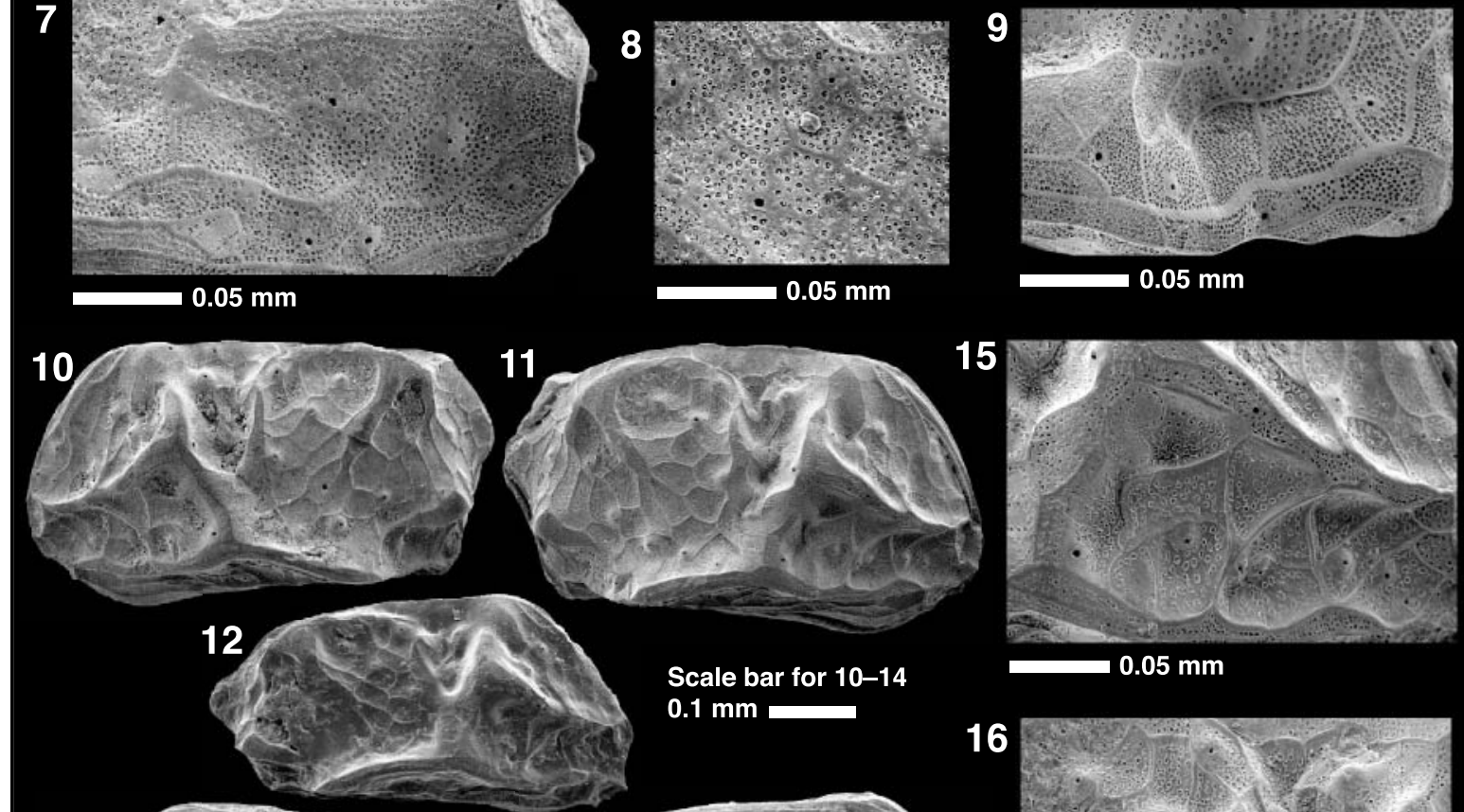

Scale bar for 10-14
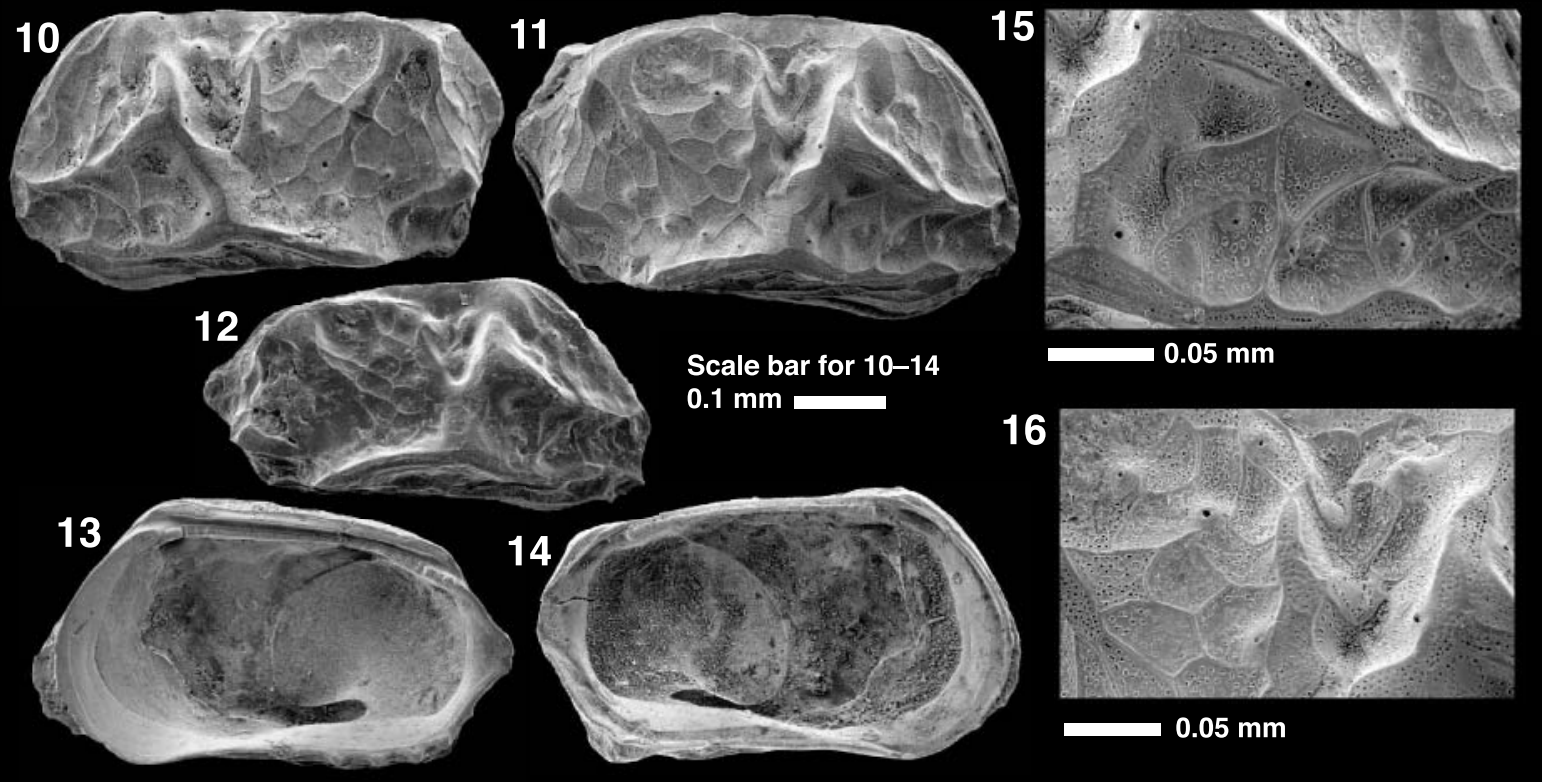

16

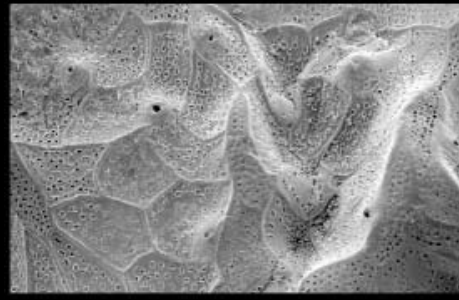

$0.05 \mathrm{~mm}$

Explanation of Plate 2.

figs 1-9. Semicytherura leptosubundata sp. nov.: 1, male, right valve (holotype, MPC-02997); 2, female, left valve (paratype, MPC-03002); 3, female, left valve from inside (paratype, MPC-02998); 4, female, right valve (paratype, MPC-02999); 5, male, left valve (paratype, MPC-03001); 6, female, right valve from inside (paratype, MPC-03000); 7, close-up view of reticulations, spines and pores in antero-ventral area of male on right valve (holotype, MPC-02997); 8, close-up view of reticulations and pores in postero-dorsal area of female on right valve (paratype, MPC-02999): 9, close-up view of reticulations and pores around ala in postero-ventral area of female on left valve (paratype, MPC-03002). figs 10-16. Semicytherura tanimurai sp. nov.: 10, female, left valve (paratype, MPC-03004); 11, female, carapace, right side (holotype, MPC-03003); 12, male, right valve (paratype, MPC-03005); 13, female, right valve from inside (paratype, MPC-03006); 14, female, left valve from inside (paratype, MPC-03007); 15, close-up view of ridges, reticulations and pores in antero-ventral area of female on right valve (holotype, MPC-03003); 16, close-up view of ridges, reticulations and pores around dorso-median sulcus of female on right valve (holotype, MPC-03003). Specimens 1, 3, 5, 7, 13 from sample C304; 2, 9 from C403; 4, 8 from C506; 6, 10, 11, 14, 15, 16 from C505; and 12 from C303. 
ventro-marginal ridge. Marginal ridges surround the carapace. Very faint reticulation, except on the major ridges; numerous fine pits were observed over the carapace. The eye tubercle is inconspicuous. The carapace surface is covered with normal pores.

Hingement: in the right valve, the anterior element consists of one small tooth and two adjacent small sockets; the median element with fine teeth, many fused teeth and a smooth element in the median part; the posterior element consists of one small and rounded tooth, with two adjacent small sockets. Hinge line is arched slightly, descending towards the posterior.

Four adductor muscle scars occur in a straight, ventromedian vertical line; the uppermost and lowermost scars are semi-circular, whereas the middle two scars are slightly elongate or bone-shaped; two oval frontal scars occur in front of the upper two adductor scars. The vestibule was not observed.

Sexual dimorphism is distinct. The male carapace is more slender and longer than the female in lateral view. The marginal infoldment and prismatic layer are very broad in the male, especially in the posterior area; in the female they are not very broad.

Dimensions (mm). Holotype, $\mathrm{L}=0.53, \mathrm{H}=0.30$ (male, right valve, MPC-02997). Paratypes, $\mathrm{L}=0.54, \mathrm{H}=0.27$ (female, left valve, MPC-02998); $\mathrm{L}=0.54, \mathrm{H}=0.30$ (female, right valve, MPC02999); $\mathrm{L}=0.54, \mathrm{H}=0.30$ (female, right valve, MPC-03000); $\mathrm{L}=0.51, \mathrm{H}=0.26$ (male, left valve, MPC-03001); $\mathrm{L}=0.56, \mathrm{H}=0.32$ (female, left valve, MPC-03002).

Occurrence. Pliocene to Pleistocene, Japan; Late Pliocene Yabuta and Sasaoka formations and Early Pleistocene Omma, Haizume and Kawachi formations on the Japan Sea coast (Fig. 1).

Remarks. This species resembles Semicytherura subundata, described by Hanai (1957, p. 35, figs 3a, b; p. 39, pl. 2, figs 3a, b) from the Pleistocene Sawane Formation, central Japan, in general lateral outline of the carapace and running direction of the ventro-marginal ridge. However, it can be distinguished from $S$. subundata by its smaller valve size, valve outline and the nature of the valve surface (Fig. 3). The overall outline of this species is sub-trapezoidal in lateral view, and its dorsal margin is relatively curved. The reticulation on the valve surface of this species is very faint. This species displays no prominent ridges on the valve surface, except on one thick ridge in the postero-ventral marginal area.

The present species resembles $S$. henryhowei Hanai \& Ikeya, 1977 named by Hanai et al. (1977), figured by Yamada et al. (2005, p. 249, fig. 3), in general valve outline. However, it can be distinguished from $S$. henryhowei by its much larger valve, weaker ridge in the posterior half, more robust and thicker ridge in the ventral margin, with less depression of the valve surface in the middle area. This species is similar to $S$. kazahana of Yamada et al. (2005, p. 253, fig. 6) in general valve outline, but the present species differs from it in having a much larger valve, a weaker ridge in the mid-anterior and midposterior, and a more robust and thicker ridge in the ventral margin

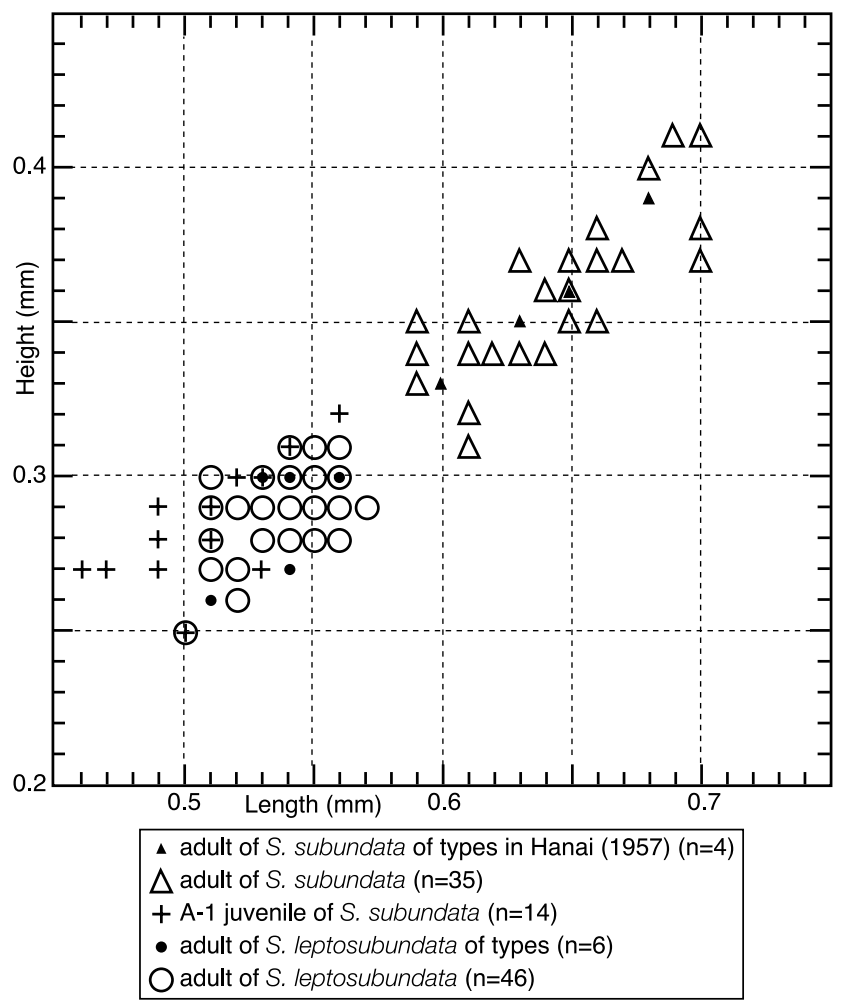

Fig. 3. Valve size (length-height) diagram of the adult and A-1 juvenile of Semicytherura subundata (Hanai, 1957) and the adult of S. leptosubundata sp. nov. Data of types of $S$. subundata from Hanai (1957) and others from original data of this study.

Semicytherura tanimurai sp. nov. (Pl. 2, figs 9-16)

1985 Semicytherura henryhowei; Ishizaki \& Matoba: pl. 7, figs 1, 2.

1996 Semicytherura sp. 6; Ozawa: 115, pl. 9, fig. 6.

Derivation of name. In honour of Dr Yoshihiro Tanimura (National Museum of Nature and Science, Tokyo, Japan), specialist in Late Cenozoic and Recent diatoms.

Diagnosis. The carapace is small, sub-rectangular and heavily calcified. The surface is ornamented by weak reticulations and strong ridges; the anterior ridge connects with one middle ridge in a T-shape; one mid-dorsal, V-shaped ridge, one ear-shaped ridge in the postero-dorsal corner. Deep dorso-median sulcus, one large shallow postero-dorsal fossa, and one prominent postero-ventral spine.

Holotype. Female, complete carapace, MPC-03003, from sample C505 (Pl. 2, figs 11, 15, 16).

Paratypes. Female, left valve, MPC-03004, from sample C505 (Pl. 2, fig. 10). Male, right valve, MPC-03005, from sample C303 (Pl. 2, fig. 12). Female, right valve, MPC-03006, from sample C304 (Pl. 2, fig. 13). Female, left valve, MPC-03007, from sample C505 (Pl. 2, fig. 14). 
Type locality and age. Sakuramachi area of Ozawa \& Kamiya (2001), the Early Pleistocene Omma Formation, Oyabe City (Fig. 1), Toyama Prefecture, central Japan (Lat. $36^{\circ} 41.1^{\prime} \mathrm{N}$, Long. $\left.136^{\circ} 52.1^{\prime} \mathrm{E}\right)$.

Description. Thick and heavily calcified carapace. Small valve, sub-rectangular in lateral view. Maximum height at the anterior cardinal angle. The dorsal margin is nearly straight in the left valve, slightly arched in the right valve. The ventral margin is slightly concave. The antero-dorsal margin is nearly straight; the antero-ventral margin, with several small spines, is arched near the ventral margin. Short and blunt caudal process, mid-height in the right valve. The posterior margin, with a slightly concave section above the posterior caudal process, has a nearly straight section below the caudal process.

The valve surface is ornamented by distinct ridges; two prominent ridges cross at approximately right angles in the anterior part; the anterior ridge, starting in the antero-ventral area, running posteriorly and terminating in the antero-median area, connects with one middle $\mathrm{T}$-shaped ridge starting at the antero-dorsal area; one strong ridge along the ventral margin. The V-shaped ridge at the mid-dorsal area surrounded by a deep dorso-median sulcus; the ear-shaped ridge at the postero-dorsal corner, surrounded by one large-shallow fossa. The marginal ridges surrounded in the carapace. The carapace surface is covered by weak reticulation, except on the major ridges. Numerous fine pits are distributed over all the carapace. One prominent spine occurs in the postero-ventral corner. The eye tubercle is indistinct. Normal pores are scattered on the valve surface.

Hingement: in the right valve, the anterior element consists of one large tooth and three adjacent small sockets; the median element has numerous fine teeth, many fused teeth especially in the median part; the posterior element consists of two small rounded teeth, with three adjacent small sockets. Hinge line is slightly arched, descending towards the posterior.

Four adductor muscle scars occur in a straight ventro-median position, in a vertical line; the uppermost and lowermost scars are semi-circular in shape, whereas the middle two scars are slightly elongate or bone-shaped; two oval frontal scars occur in front of the upper two adductor scars. The marginal infoldment and prismatic layer are very broad. The vestibule was not observed.

Sexual dimorphism is distinct. The male carapace is more slender and longer than the female in lateral view.

Dimensions (mm). Holotype, $\mathrm{L}=0.56, \mathrm{H}=0.32$ (female, carapace, MPC-03003). Paratypes, $\mathrm{L}=0.54, \mathrm{H}=0.30$ (female, left valve, MPC-03004); $\mathrm{L}=0.47, \mathrm{H}=0.27$ (male, right valve, MPC-03005); $\mathrm{L}=0.54, \mathrm{H}=0.32$ (female, right valve, MPC-03006); $\mathrm{L}=0.54$, $\mathrm{H}=0.30$ (female, left valve, MPC-03007).

Occurrence. Pliocene to Pleistocene, Japan; Late Pliocene Sasaoka Formation and Early Pleistocene Omma, Nishiyama, Haizume, Kawachi, Kaidate, Kitaura, Setana, Wakimoto and Shichiba formations along the Japan Sea coast (Fig. 1).

Remarks. This species resembles Semicytherura subundata (Hanai, 1957, p. 35, figs 3a, b; p. 39, pl. 2, figs 3a, b) in general external carapace ornamentation. However, it differs from S. subundata in its smaller valve size, different valve outline and the nature of the valve surface. The overall outline of this species is sub-rectangular in lateral view, and it possesses two prominent ridges forming a V-shape and ear-shape around the dorsomedian sulcus and at the postero-dorsal area. The anterior T-shaped ridge is more prominent than in S. subundata, which displays a deep dorso-median sulcus, and a large fossa in the postero-dorsal corner and a large postero-ventral spine.

The present species also resembles in general shape Semicytherura balrogi (Brouwers, 1994, pl. 5, figs 15-18; pl. 6, figs 1, 2; pl. 7, figs 1-3, 6) from Holocene sediments of the Gulf of Alaska, and Semicytherura henryhowei Hanai \& Ikeya, 1977, figured by Yamada et al. (2005, p. 247, fig. 2A; p. 249, fig. 3A-I) from the Recent Pacific coast of central Japan. However, it can be distinguished from these two species by its more angular carapace outline, deeper dorso-median sulcus surrounded by a prominent $\mathrm{V}$-shaped ridge, distinct marginal ridges, and strong, antero-median $\mathrm{T}$-shaped ridge.

The present species is similar to Semicytherura sp. 5 of Irizuki (1994, pl. 3, figs 16, 17) from the Late Miocene Fujikotogawa Formation, north Japan, in general outline. It can be distinguished in having a much larger valve, different ridge patterns in the middle to posterior half, and in the differently shaped median sulcus.

The present species is similar to Semicytherura sp. A of Cronin \& Ikeya (1987, pl. 3, fig. 10) from the Early Pleistocene Setana and Sawane formations, central and north Japan, in general carapace outline and carapace size. However, S. tanimurai differs in having a straight dorsal line with a weaker and shorter ridge in the dorso-posterior to mid-ventral region.

\section{DISCUSSION}

\section{Speciation and extinction in the Japan Sea for each newly described Semicytherura}

Semicytherura robustundata. An undescribed species closely related to Semicytherura robustundata first occurred in the Japan Sea coast in the Late Miocene (8-7 Ma, Fujikotogawa Formation; Semicytherura sp. 2 and Semicytherura sp. 4 of Irizuki, 1994) and in the Pliocene (4-3 Ma, Ogikubo Formation; Ozawa, pers. obs.). S. robustundata first appeared in the Japan Sea in the Late Pliocene (around $2 \mathrm{Ma}$, Sasaoka Formation; Yamada et al., 2002), occurring only in this area until 1.2 Ma (Hamada and Kitaura formations; Sugawara et al., 1997; Sato et al., 1999). Therefore, the species group containing $S$. robustundata must have originated in the Japan Sea from the Late Miocene (8-7 Ma). S. robustundata was reported in the Japan Sea from 2.0-1.2 $\mathrm{Ma}$ in age and has been extinct since 1.2 Ma.

In the Arctic Ocean, the related and similar species Semicytherura undata abruptly occurred in the Late Pliocene (c. 3 Ma, Tjörnes beds; Cronin, 1991). This is the oldest fossil record of the Semicytherura group containing $S$. robustundata (Yamada et al., 2005). This suggests that this species group originated in the northwestern Pacific in the Late Miocene and then migrated to the Arctic Ocean through the Bering Sea. Subsequently, $S$. undata appeared in the Arctic Ocean in the Late Pliocene at the latest. S. undata inhabits a wide geographical area in the present Arctic and north Atlantic oceans. 


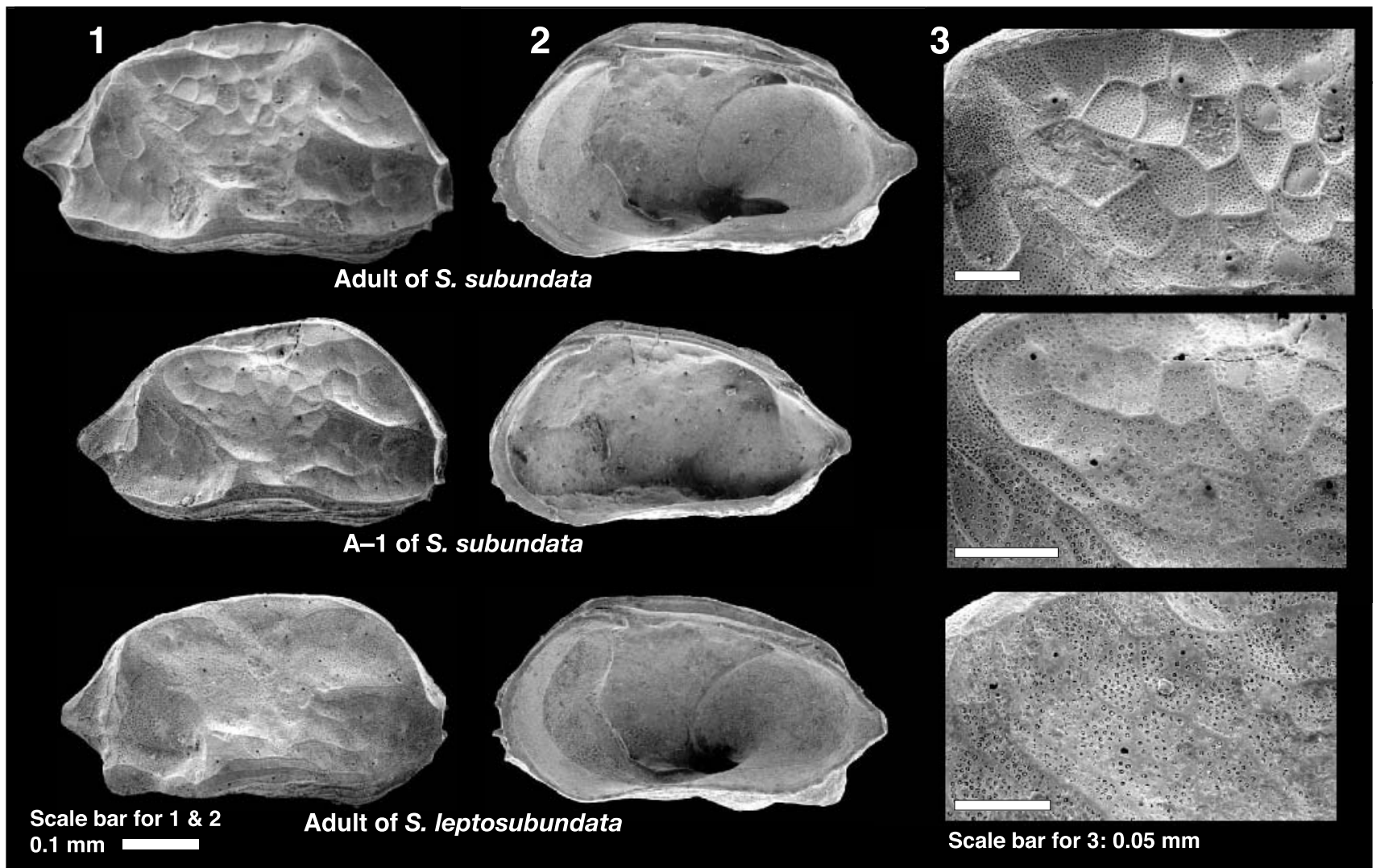

Fig. 4. Comparison of the lateral view (adult and A-1 juvenile) of the right valve of Semicytherura subundata (Hanai, 1957) and S. leptosubundata sp. nov. from the Early Pleistocene Kaidate Formation, central Japan. (1) Lateral view; (2) lateral view from inside; (3) close-up view of reticulations and ornaments in postero-dorsal area. Upper, adult of $S$. subundata; middle, A-1 juvenile of $S$. subundata; lower, adult of $S$. leptosubundata.

Semicytherura subslipperi. Unnominated species closely related to Semicytherura subslipperi occurred in the Japan Sea coast in the Late Miocene (8-7 Ma; Semicytherura sp. 3 of Irizuki, 1994). S. subslipperi first appeared in the Japan Sea in the Late Pliocene (c. 3 Ma, Yabuta and Kuwae formations; Cronin et al., 1994; Irizuki et al., 2007) and was distributed only in this area until 1.0 Ma (Haizume Formation; Sato et al., 1999). Therefore, this species group must have originated in the Japan Sea within the Late Miocene. S. subslipperi was then later established in the Japan Sea from c. 3-1 Ma before becoming extinct at $1 \mathrm{Ma}$.

Another similar species belonging to this group, S. slipperi, inhabits a restricted area of the northwestern Pacific coast of Hokkaido (Yamada et al., 2005). The close similarity of the distributional patterns of pores in the same molt stage between ostracod species strongly suggests their close phylogenetic relationship (e.g. Tsukagoshi, 1990). Comparing distributional patterns of pores on adult carapaces, the position of one pore on the anterior ridge of this species is different from that of $S$. slipperi (Fig. 2). This fact suggests that although these species are different, they are very closely related phylogenetically. $S$. slipperi has been reported only in modern sediments from the Hokkaido coast in northern Japan, despite detailed investigation for any potential fossil and modern distribution by Yamada et al. (2005). Recently, several specimens of another similar, but undescribed species, $S$. cf. subslipperi were reported from Early Pleistocene strata (1 Ma) from the Japan Sea coast, differing in position of some of the anterior pores. Therefore, this species group diversified and became extinct several times in and around the Japan Sea during the Late Cenozoic.

Semicytherura leptosubundata. The general external morphology, general valve outline, carapace size and degree of reticulation in Semicytherura leptosubundata are very similar to those in the A-1 juvenile of $S$. subundata (Figs 3 and 4), except for some features such as the marginal infold area and prismatic layer of the internal carapace.

S. subundata first occurred in the Japan Sea in the Late Miocene (8-7 Ma; Irizuki, 1994) and was also present in the Pliocene (4-3 Ma, Ogikubo Formation; Ozawa, unpublished data). This species occurred in the Japan Sea until $0.1 \mathrm{Ma}$ (Anden Formation; Ozawa \& Kamiya, 2005). S. leptosubundata first occurred in the Late Pliocene (c. 3 Ma, Yabuta Formation; Cronin et al., 1994) in the Japan Sea. The youngest fossil record of this species is from the Early Pleistocene Kawachi Formation (c. 1.0 Ma; Ozawa \& Kamiya, 2005), suggesting its extinction after $1 \mathrm{Ma}$.

The similarity of the distributional patterns and number of pores in the same molt stage between podocopid ostracod taxa at various levels (species, genus and family) strongly suggests their close phylogenetic relationship (Tsukagoshi, 1990; Irizuki, 1993; Kamiya, 1997; Smith \& Kamiya, 2005). The distributional 


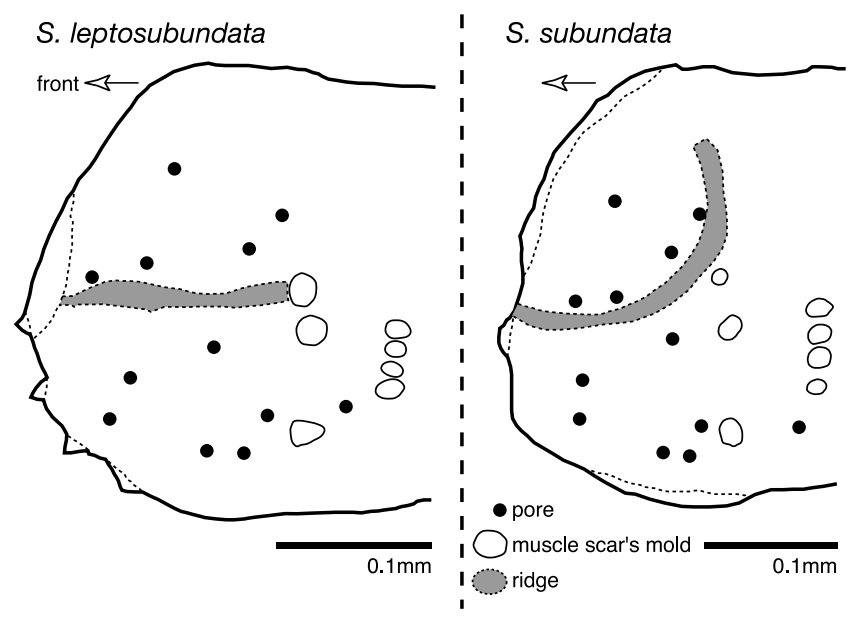

Fig. 5. Positions of the correlated 12 pores on the anterior part of the left valve of Semicytherura leptosubundatasp. nov. and S. subundata (Hanai, 1957).

pattern of pores in the anterior part in the adult stage is also very similar between these two species, which have the same number of pores (Fig. 5). Patterns and numbers in the anterior part are different from those of other Semicytherura species such as $S$. henryhowei and S. kazahana, as shown by Yamada et al. (2005). Thus, S. leptosubundata and $S$. subundata are considered to have a close phylogenetic relation within this genus.

Taking the adult form of $S$. subundata as a standard, the morphological characters of $S$. leptosubundata on its carapace surface and valve size can be explained in terms of paedomorphosis. The carapace size (length and height), general outline and the faint reticulation on the valve surface of the adult $S$. leptosubundata are more similar to the A-1 juvenile of $S$. subundata than those of the adult of S. subundata (Figs 3 and 4).

Similar heterochronic examples of paedomorphosis in the carapace size, general valve outline, surface ornamentation, hingement and marginal infoldment in podocopid ostracods have been found between many pairs of species in the Superfamily Cytheracea (Families Cytheridae, Leptocytheridae, Hemicytheridae, Cytheruridae and Loxoconchidae) from the Late Cenozoic in Japan (Kamiya, 1992; Tsukagoshi, 1994; Tsukagoshi \& Kamiya, 1996; Tanaka \& Ikeya, 2002). Comparing the adult of $S$. leptosubundata and the A-1 of $S$. subundata, the development degree of several ridges, marginal infoldment and hingement is not so similar. However, heterochronic change is not always observed in the whole body plan simultaneously. According to Tsukagoshi \& Kamiya (1996), heterochronic relationships can be found only in the morphology of some particular characters in most cases. They stated that such morphological changes are easy to explain by a lag in development programming, because these morphological characters often change abruptly during the ontogeny of a species. Therefore, the reticulation and carapace size are certainly two of the features reflecting heterochronic change. So the S. leptosubundata and $S$. subundata pair is one of these heterochronic examples showing paedomorphic evolution, found to be restricted in the Japan Sea in the Late Pliocene at the latest.

Due to their relevant geological-geographical occurrences and carapace morphologies, S. leptosubundata is probably derived directly from $S$. subundata around the Late Pliocene (3 Ma) within the Japan Sea and was restricted in this area from 3-1 Ma.

Semicytherura tanimurai. Some undescribed species that appear to be closely related to Semicytherura tanimurai occurred along the Japan Sea coast from the Late Miocene (8-7 Ma; Semicytherura sp. 5 of Irizuki, 1994) and in the Early to Late Pliocene (4-3 Ma, Ogikubo Formation; Ozawa, pers. obs.). $S$. tanimurai first occurred in the Japan Sea in the Late Pliocene (Sasaoka Formation, c. 2 Ma; Yamada et al., 2002), where it remained until 0.5 Ma (Shichiba Formation; Kato et al., 1995), restricted to the Japan Sea.

These data suggest that the species group comprising $S$. tanimurai developed in the Japan Sea from the Late Miocene. $S$. tanimurai was then distributed in the Japan Sea from 2.0$0.5 \mathrm{Ma}$, before becoming extinct around $0.5 \mathrm{Ma}$. Another undescribed but closely related species with S. tanimurai (Semicytherura sp. in Ozawa et al., 1999, table 1) was found in modern sediment obtained east of Rebun Island at depths of $60 \mathrm{~m}$ in the northeastern Japan Sea. This species group diversified and became extinct several times in and around the Japan Sea during the Late Cenozoic, similar to species in the $S$. subslipperi group.

\section{Diversity changes in four Semicytherura species and related species}

Semicytherura in and around the Japanese Islands are largely divisible into the six Groups A-F, as described by Yamada et al. (2005), based on their carapace outlines and reticulation. They stated that this division reflects phylogenetically related groups within this genus. It is considered that all four Semicytherura species described here belong to Yamada et al.'s Group A ( $S$. henryhowei group), based on the similarity of carapace shape, the general outline, morphology of the caudal process, development of large triangular fossa and the prominent $\mathrm{T}$-shaped ridge in the anterior area, and marginal ridges in the posterior area.

According to Yamada et al. (2005), species of Group A originated in the northwestern Pacific in, or around, Japan until the Middle Miocene, based on the fossil occurrences. Recently, Irizuki et al. (2004) described Semicytherura pseudoundata as a new species from the Early Miocene strata (18 Ma) in central Japan, and stated that its carapace morphology is similar to that of $S$. henryhowei. Thus, the probable ancestor of the four Semicytherura species described here may have first occurred in the northwestern Pacific from the Early Miocene at the latest.

After that, all four species diversified within the Japan Sea until the Late Pliocene (3-2 Ma). From the Late Miocene to Late Pliocene, the southern strait of the Japan Sea was landlocked or mostly closed, even in interglacial and high sea-level periods (Iijima \& Tada, 1990; Koizumi, 1992). Therefore, this sea was almost isolated in this period, although the southern strait opened frequently during almost each inter-glacial period after 2 Ma (e.g. Kitamura \& Kimoto, 2004). The isolation of the Japan Sea in this period would have encouraged the diversification or speciation of its ostracod inhabitants. These four species were endemic to the Japan Sea in the Pliocene and Pleistocene, and inhabited the sea until their extinction during the later period of the Early Pleistocene. 
Yamada et al. (2005) summarized the geological and geographical occurrence of Group A species reported globally. According to their summary, Group A species appeared in the north Atlantic, first in the Late Pliocene along the coast of Iceland (S. undata; Cronin, 1991). One Group A species (Semicytherura sp. B of Whatley \& Boomer, 1995) was dated to the Late Pleistocene in the northeastern Pacific near California; this is the oldest fossil record of this group in the northeastern Pacific. In the Arctic, northern Atlantic and northwestern Pacific oceans, many specimens of three species in Group A have been reported from Holocene to Recent samples.

These occurrences indicate that Group A species originated in the northwestern Pacific region from the Early Miocene. After that, part of the species migrated northwards through the Bering Sea to the Arctic Ocean, and reached the North Atlantic Ocean around the Late Pliocene. Another group migrated to lowlatitude areas along the west coast of North America, reaching the northeastern Pacific region and remaining until the Late Pleistocene.

The geographical and geological distributions of the four Semicytherura species (Fig. 1) suggest that they originated along the Japan Sea coasts and diversified within this sea until the Late Pliocene. These Semicytherura then became extinct during the later period of the Pleistocene (after $c$. $1 \mathrm{Ma}$ ), as suggested by the youngest fossil record of each species in Ozawa \& Kamiya (2005) and additional data of this study. As discussed by Ozawa \& Kamiya (2005), the extinction of these Semicytherura species with 18 species in the Families Hemicytheridae and Eucytheridae was caused by the occurrence of low-salinity water at the Japan Sea surface during glacial and low sea-level periods since the Early Pleistocene, related to glacio-eustatic sea-level changes.

Another Semicytherura species living outside of the Japan Sea, S. undata, has a much wider distribution in the Arctic, northeastern and northwestern Atlantic oceans (e.g. Hazel, 1970) than the four Semicytherura species, and inhabits various salinity conditions (10-35\%; e.g. Penney, 1989). These four Semicytherura species were also more prone to extinction in the Pleistocene Japan Sea due to their narrow salinity tolerance range (inferred around 34\%0; Ozawa \& Kamiya, 2005) and relatively narrow geographical distribution within the Japan Sea (Fig. 1).

Alternatively, species groups of Semicytherura including the four described species had speciated several times during the Late Cenozoic in, or around, the Japan Sea, especially in the two species groups of $S$. subslipperi and $S$. tanimurai during the Pliocene. Furthermore, Group A species in Japan also diversified several times in the Miocene and Pliocene, and these frequent speciation events were probably related to fluctuations in shallow-marine environments in this period in and around the middle latitude areas of the Japan Sea. However, it is still uncertain whether closely related, but as yet informally described species from the Miocene and Pliocene strata from the Japan Sea coasts, are exactly the same as species from the Pleistocene, and how many times speciation occurred in this sea in the Miocene-Pliocene. It is not possible to judge the appropriate classification of poorly preserved specimens of species having similar carapace morphology to this genus, without detailed observation of the pore distribution.

\section{ACKNOWLEDGEMENTS}

The authors would like to thank Y. Tanimura (National Museum of Nature and Science, Tokyo) for kind assistance in various aspects of preparing the manuscript and the registration of specimens. N. Ikeya, A. Tsukagoshi (Shizuoka University) and S. Yamada (University of Tokyo) are thanked for valuable suggestions for ostracod taxonomy and supply of fossil samples. Thanks are also due to H. Takata (Pusan University), A. Nojo (Hokkaido University of Education), K. Abe (Tsukuba University), T. Ishii, T. Sato (Kanazawa University) and the late T. Matsuzaka for supply of fossil samples and for access to literature. T. Irizuki (Shimane University) and E. M. Brouwers (US Geological Survey) provided constructive reviews, while the editor F. J. Gregory (PetroStrat Ltd) helped improve the manuscript. This study was supported partly by Grant-in-Aid for JSPS Research Fellow for Young Scientists (06372 to H. Ozawa).

\section{Manuscript received 15 January 2007 Manuscript accepted 6 August 2008}

\section{REFERENCES}

Athersuch, J., Horne, D.J. \& Whittaker, J.E. 1989. Marine and brackish water ostracods. In: Kermack, D.M. \& Barnes, R.S.K. (Eds), Synopses of the British Fauna. (New Series), 43. The Linnean Society of London and The Estuarine and Brackish-Water Sciences Association, E.J. Brill, Leiden, 343pp.

Brouwers, E.M. 1994. Systematic paleontology of Quaternary ostracode assemblages from the Gulf of Alaska. Part 3: Family Cytheruridae. U.S. Geological Survey Professional Paper, 1544: 1-43.

Cronin, T.M. 1991. Late Neogene marine Ostracoda from Tjörnes, Iceland. Journal of Paleontology, 65: 767-794.

Cronin, T.M. \& Ikeya, N. 1987. The Omma Manganji ostracode fauna (Plio-Pleistocene) of Japan and the zoogeography of circumpolar species. Journal of Micropalaeontology, 6: 65-88.

Cronin, T.M., Kitamura, A., Ikeya, N., Watanabe, M. \& Kamiya, T. 1994. Late Pliocene climate change 3.4-2.3 Ma: paleoceanographic record from the Yabuta Formation, Sea of Japan. Palaeogeography, Palaeoclimatology, Palaeoecology, 108: 437-455.

Hanai, T. 1957. Studies on the Ostracoda from Japan, III. Subfamilies Cytherurinae G.W. Müller (emend. G.O. Sars, 1925) and Cytheropterinae, new subfamily. Journal of Faculty of Sciences, University of Tokyo, 11: 11-36.

Hanai, T., Ikeya, N., Ishizaki, K., Sekiguchi, Y. \& Yajima, M. 1977. Checklist of Ostracoda from Japan and its adjacent seas. University Museum, University of Tokyo Bulletin, 12: 1-119.

Hazel, J.E. 1970. Atlantic continental shelf and slope of the United States. Ostracode zoogeography in the southern Nova Scotian and Virginian Faunal Provinces. US Geological Survey, Professional Paper, Washington, 529-E: 1-21.

Iijima, A. \& Tada, R. 1990. Evolution of Tertiary sedimentary basins of Japan in reference to opening of the Japan Sea. Journal of Faculty of Sciences, University of Tokyo, Sec II, 22: 121-171.

Ikeya, N., Tanaka, G. \& Tsukagoshi, A. 2003. Ostracoda. In: Ikeya, N., Hirano, H. \& Ogasawara, K. (Eds), The database of Japanese fossil type specimens described during the 20th Century (Part 3). Palaeontological Society of Japan, Special Papers, 41: 37-131.

Irizuki, T. 1993. Morphology and taxonomy of some Japanese hemicytherin Ostracoda - with particular reference to ontogenetic changes of marginal pores. Transactions and Proceedings of Palaeontological Society of Japan, 170: 186-211.

Irizuki, T. 1994. Late Miocene ostracods from the Fujikotogawa Formation, northern Japan - with reference to cold water species involved with trans-Arctic interchange. Journal of Micropalaeontology, 13: 3-15. 
Irizuki, T., Yamada, K., Maruyama, T. \& Ito, H. 2004. Paleoecology and taxonomy of early Miocene Ostracoda and paleoenvironment of the eastern Setouchi Province, central Japan. Micropaleontology, 50: $105-147$.

Irizuki, T., Kusumoto, M., Ishida, K. \& Tanaka, Y. 2007. Sea-level change and water structures between 3.5 and $2.8 \mathrm{Ma}$ in the central part of the Japan Sea Borderland: Analysis of fossil Ostracoda from the Pliocene Kuwae Formation, central Japan. Palaeogeography, Palaeoclimatology, Palaeoecology, 245: 421-433.

Ishizaki, K. \& Matoba, Y. 1985. Excursion 5, Akita (Early Pleistocene cold, shallow water Ostracoda). In: Ikeya, N. (Ed.), Guidebook of Excursions for 9th International Symposium of Ostracoda, Shizuoka. Organising Committee of 9th ISO, Shizuoka, 1-12.

Kamiya, T. 1992. Heterochronic dimorphism of Loxoconcha uranouchiensis (Ostracoda) and its implication for speciation. Paleobiology, 18: 221-236.

Kamiya, T. 1997. Phylogeny estimated from fossil information-the pore systems of Ostracoda. Iden (Genetics), 51: 28-34 [in Japanese, title translated].

Kato, M., Akada, K., Takayama, T., Goto, T., Sato, T., Kudo, T. \& Kameo, K. 1995. Calcareous microfossil biostratigraphy of the uppermost Cenozoic Formation distributed in the coast of the Japan Sea 'Sawane Formation'. Annual Science Report of Kanazawa University, 32: 21-38 [in Japanese with English abstract].

Kitamura, A. \& Kimoto, K. 2004. Reconstruction of the southern channel of the Japan Sea at 3.9-1.0 Ma. The Quaternary Research (Daiyonki-Kenkyu), 43: 417-434 [in Japanese with English abstract].

Koizumi, I. 1992. Biostratigraphy and paleoceanography of the Japan Sea based on diatoms: ODP Leg 127. In: Tsuch, R. \& Ingle, J.C. Jr (Eds), Pacific Neogene: environment, evolution, and events. University of Tokyo Press, Tokyo, 15-24.

Okubo, I. 1980. Six species of the subfamily Cytherurinae Müller, 1894, in the Inland Sea, Japan (Ostracoda). Publications of Seto Marine Biological Laboratory, 25: 7-26.

Ozawa, H. 1996. Ostracode fossils from the late Pliocene to early Pleistocene Omma Formation in the Hokuriku district, central Japan. Science Report of Kanazawa University, 41: 77-115.

Ozawa, H. 2007. Faunal changes of cryophilic ostracods (Crustacea) in the Japan Sea, in relation to oceanographic environment: an overview. Fossils (Palaeontological Society of Japan), 82: 22-30 [in Japanese with English abstract].

Ozawa, H. \& Kamiya, T. 2001. Palaeoceanographic records related to glacio-eustatic sea-level fluctuations in the Pleistocene Japan Sea coast based on ostracods from the Omma Formation. Palaeogeography, Palaeoclimatology, Palaeoecology, 170: 27-48.

Ozawa, H. \& Kamiya, T. 2005. The effects of glacio-eustatic sea-level change on Pleistocene cold-water ostracod assemblages from the Japan Sea. Marine Micropaleontology, 54: 167-189.

Ozawa, H., Ikehara, K. \& Katayama, H. 1999. Recent ostracode fauna in the northeastern part of the Japan Sea, off northwestern Hokkaido. In: Ikehara, K. \& Okamura, Y. (Eds), Comprehensive study on environmental changes in the western Hokkaido coastal area and study on evaluation of marine active faults. Geological Survey of Japan, Tsukuba, 103-117 [in Japanese, title translated].

Penney, D.N. 1989. Recent shallow marine Ostracoda of the Ikerssuak (Bredefjord) District, Southwest Greenland. Journal of Micropalaeontology, 8: 55-75.

Sars, G.O. 1866. Oversigt af Norges marine Ostracoder. Forhandlingen Videnskabs-Selskabet I Christiana, 1865: 1-130.

Sato, T., Takayama, T., Kato, M. \& Kudo, T. 1987. Calcareous microfossil biostratigraphy of the upper most Cenozoic Formations distributed in the coast of the Japan Sea - part 1: Niigata area. Journal of Japanese Association for Petroleum Technology, 52: 231-242 [in Japanese with English abstract].

Sato, T., Kameo, K. \& Mita, I. 1999. Validity of the latest Cenozoic calcareous nannofossil datums and its implication to the tephrachronology. Earth Science (Chikyu-Kagaku), 53: 265-274 [in Japanese with English abstract].

Smith, R.J. \& Kamiya, T. 2005. The ontogeny of the entocytherid ostracod Uncinocythere occidentalis (Kozloff \& Whitman, 1954) Hart, 1962 (Crustacea). Hydrobiologia, 538: 217-229.

Sugawara, H., Yamaguchi, T. \& Kawabe, T. 1997. Geological age of the Hamada Formation in the eastern Shimokita Peninsula, Aomori Prefecture. Fossils (Palaeontological Society of Japan), 62: 15-23 [in Japanese with English abstract].

Takata, H. 2000. Paleoenvironmental changes during the deposition of the Omma Formation (late Pliocene to early Pleistocene) in Oyabe area, Toyama Prefecture based on the analysis of benthic and planktonic foraminiferal assemblages. Fossils (Palaeontological Society of Japan), 67: 1-18 [in Japanese with English abstract].

Tanaka, G. \& Ikeya, N. 2002. Migration and speciation of the Loxoconcha japonica species group (Ostracoda) in East Asia. Paleontological Research, 6: 265-284.

Tsukagoshi, A. 1990. Ontogenetic change of distributional patterns of pore systems in Cythere species and its phylogenetic significance. Lethaia, 23: 225-241.

Tsukagoshi, A. 1994. Natural history of the brackish-water ostracode genus Ishizakiella from East Asia: evidence for heterochrony. Journal of Crustacean Biology, 14: 295-313.

Tsukagoshi, A. \& Kamiya, T. 1996. Heterochrony of the ostracod hingement and its significance for taxonomy. Biological Journal of the Linnean Society, 57: 343-370.

Wagner, C.W. 1957. Sur les Ostracodes du Quaternaire récent des Pays-Bas et leur utilisation dans l'étude géologique des dépots Holocènes. Mouton \& Co., Hague, 259pp.

Whatley, R. \& Boomer, I. 1995. Autochthonous and allochthonous Quaternary Ostracoda from Site 893, Santa Barbara Basin. Proceeding of the Ocean Drilling Program, Scientific Results, 146: 251-255.

Yamada, K., Irizuki, T. \& Tanaka, Y. 2002. Cyclic sea-level changes based on fossil ostracode faunas from the upper Pliocene Sasaoka Formation, Akita Prefecture, central Japan. Palaeogeography, Palaeoclimatology, Palaeoecology, 185: 115-132.

Yamada, S., Tsukagoshi, A. \& Ikeya, N. 2005. Taxonomy, morphology and speciation of the Semicytherura henryhowei group (Crustacea, Ostracoda). Hydrobiologia, 538: 243-265. 